\title{
Ergonomic analysis in an animal feed company: demands and work environment
}

João Eduardo Linhares jelinhares@gmail.com Universidade Tecnológica Federal do Paraná (UTFPR), Pato Branco, Paraná, Brasil

Sergio Luiz Ribas Pessa slpessa@utfpr.edu.br Universidade Tecnológica Federal do Paraná (UTFPR), Pato Branco, Paraná, Brasil

\section{Gilson Adamczuk Oliveira}

gilson@utfpr.edu.br
Universidade Tecnológica Federal do

Universidade Tecnológica Federal do

Brasil

Marcelo Gonçalves Trentin marcelo@utfpr.edu.br

Universidade Tecnológica Federal do Paraná (UTFPR), Pato Branco, Paraná, Brasil

\author{
ABSTRACT
}

The ergonomic evaluation of work aims to care for the health of the worker and instruct the preparation of a work project capable of increasing the productivity of the company. The aims was to perform an ergonomic analysis of an animal feed company, based on the perception of the workers and the opinion of ergonomics experts. The study was based on the ergonomic assessment phase of the Macroergonomic Work Analysis (MWA), using tools such as the method of Macroergonomic Design (MD) and the Discomfort Questionnaire (DQ). The general perception of the workers was satisfaction with the environment, organization and content of work. Some complaints were reported as noise with mean $5.57(M=5.57)$, temperature $(M=5.27)$, and the presence of aerodispersoids in the workplace environment $(M=5.02)$. In work organization, the unloading $(M=2.87)$, loading $(M=4.27)$ and maintenance $(M=5.99)$ sectors showed low satisfaction levels as to the number of employees performing the tasks. The workers reported low perception of discomfort $(M=0.46)$, but in each sector there were some complaints of pain in certain body parts. The study showed that the collaborative dynamic of the workers, as is defined in the MWA method, together with the application of the MD and DQ tools, was sufficient in the construction of an ergonomic diagnosis to instruct a work project for the company.
\end{abstract}

KEYWORDS: Macroergonomics. Macroergonomic design. Work project. Discomfort. 


\section{INTRODUCTION}

The technological development of machines, equipment and vehicles during World War II and industrial intensification in the post-war period resulted in a greater concern for the health of workers and the productivity of industry (PESSA, 2010; VILLAROUCO; ANDRETO, 2008). It was from studies conducted in this period that ergonomics emerged as a formal science (IIDA, 2005; GUIMARÃES, 2002).

The workload is characterized by the relationship between human performance in work activities and the way the person understands their job (KURATA; BANO; MATIAS, 2015). Ergonomic analyses, from the analysis of the workload, identify which factors negatively influence the work project, such as inadequate postures, heavy load handling and unnecessary tasks (GUIMARÃES et al., 2015). Ergonomics therefore presents itself as an instrument to increase productivity, emphasizing the importance of the workers and aiming to provide better work conditions (VILLAROUCO; ANDRETO, 2008). Ergonomics studies also contribute to the enhancement of the work project (CORLETT; MANENICA, 1980), thereby improving the environmental conditions for the work. Still, it is worth noting that ergonomics seeks to value the importance of human capital in an organization (LUZ et al., 2016).

A worker can spend their entire life in the same company, performing the same tasks. The posture adopted for the execution of the tasks can become repetitive and even damage the musculature of the individual over the years (CORLETT; MANENICA, 1980). The loading of cargo, for example, requires a greater physical effort. This task leads to physical overload, and the adoption of a poor posture can contribute to the development of muscle and bone diseases (ORMELEZ; ULBRICHT, 2013).

According to the World Health Organization, the pain related to work (WMSDs) may be associated with multiple factors, such as physical demands, psychosocial factors, and individual peculiarities (METHA; AGNEW, 2011). The workload is therefore greatly influenced by physical exertion, as well as mental effort. The way that the worker responds to the workload is something individual, a subjective experience. The perception of discomfort or pain, obtained from a physiological response, varies according to the imposed workload (GUIMARÃES; PESSA; BIGUELINI, 2012; TRENTIN; OLIVEIRA; SETTI, 2012). This perception greatly influences both the ability to work and the worker's quality of life (SÖRENSEN et al., 2008). The performance of an activity on a machine with an inadequate working height, for example, can result in a curved spine (CORLETT; MANENICA, 1980). Hence ergonomics plays a critical role in providing better working conditions.

Given this reality, this study sought to conduct an ergonomic analysis in an animal feed company, with the intention to assess demands and work environment from the perspective of the worker and also from a scientific view. The study was structured as follows: introduction and theoretical framework; material and methods; analysis and discussion of the data; conclusions. 


\section{THEORETICAL FRAMEWORK}

The study of the work environment is important for adapting the physical space occupied by the workers, mainly with regard to the use and accessibility of the buildings and environments with the circulation of these people, taking into account their physical, cultural, personal and emotional characteristics and limitations (SOARES, 2009).

The actions taken to better working conditions are the result of that which ergonomics can offer to organizations and their employees. The nature of these improvements may involve physical improvements in the environment and the workstation, and also the organization of work (PESSA, 2010).

It is important to note that micro and small businesses, when it comes to investment analysis, encounter difficulties in implementing ergonomic actions, as they are restricted to the obligations imposed by regulatory and inspection agencies (PEGATIN et al., 2008). On the other hand, studies show that with the implementation of an efficient ergonomic evaluation, the company can gain productivity, either through the reorganization of the work project, or through the preventative actions for the health of the worker (CORNELLI, 2010).

It is important to understand that the content of this study is not restricted only to physical workload. Both mental load, which brings together the psychological and cognitive aspects of the task, and the psychological load, which refers to the loads related to the affective interactions between the workers and their work, make up the content of the work, being important to evaluate these issues (BRIDGER, 1995). Therefore, an approach focused on the implementation of improvements based on the reduction of heavy mental-physical workloads is important, even though this approach is time-consuming for both managers and workers and requires thorough and thoughtful planning (VINK et al., 1995).

According to Kleiner (2006), macroergonomics is the study of work systems, characterized by a group of two or more people, interacting with a technological system within an internal, physical and cultural system (KLEINER, 2006). Cornelli (2010), states that macroergonomics is focused on human beings, and that one of the essential macroergonomic methodologies is participative ergonomics.

Thus, macroergonomics arises as a way to implement an ergonomics program in the company (GUIMARÃES, 2002). Within the ergonomic action methods, Cornelli (2010), highlights at least three: Ergonomic Workplace Analysis (WEA); Ergonomic Intervention; and Macroergonomic Work Analysis (MWA).

The Macroergonomic Work Analysis (MWA) by Guimarães (2002) identifies the problems of work from the point of view of both workers and ergonomists, and counts on the participation of the workers and proposes methodological guidance for the action research (GUIMARÃES, 2002; CORNELLI; GUIMARÃES, 2012; BITENCOURT; GUIMARÃES, 2012). The MWA is composed of the following phases: 0 - launch of the project; 1 - ergonomic survey or assessment; 2 - analysis of the situation or ergonomic diagnosis; 3 - proposal of solutions; 4 - validation of solutions; and 5 - ergonomic detailing (GUIMARÃES, 2002).

To carry out phase 1 of the MWA, ergonomic survey or assessment, three stages of the Macroergonomic Design (MD) tool are used, as proposed by Fogliatto and Guimarães (1999). These stages are comprised of (i) user 
identification and organized collection of information on the ergonomic demand, (ii) prioritization of ergonomic demand items (EDIs) identified by the users, and (iii) incorporation of ergonomic experts' opinion (FOGLIATTO; GUIMARÃES, 1999).

The participation of the user in the ergonomic assessment stages has great importance, as they are closer to the demands and work environment, and their opinion is essential for the MWA to be implemented in the organization (GUIMARÃES, 2002; CORNELLI; GUIMARÃES, 2012; BITENCOURT; GUIMARÃES, 2012). Furthermore, the participatory approach is able to promote the engagement of the workers, as they begin to better understand their work demands (PESSA, 2010).

Thus, the ergonomic evaluation, supported by these tools, is able to provide an ergonomic diagnosis that will serve as the basis of the organization's work project (GUIMARÃES, 2002).

\section{METHODS}

The present study is characterized by an exploratory study, with the application of questionnaires and the assessment of ergonomic experts. The research showed quantitative (discrete) data, with a collection of cross-sectional data (of a determined period) (CAUCHICK et al., 2012).

For this study, the recommendations from phase 1 of the MWA were used, with the purpose of proposing an ergonomic assessment of the animal feed company. The method suggests that this is the most important phase of the process, as the success of the survey enables a greater success in the intervention (GUIMARÃES, 2002).

Consideration was given in two dimensions: the first, with the direct participation of the workers; second, the inclusion of the opinion of experts. Although the method is participatory, the MWA has a systematic nature, permitting an evaluation of the whole process, serving as a tool for the evaluation of the production process (CORNELLI, 2010).

Phases (ii) and (iii) of Macroergonomic Design (MD) (KLEINER, 2006) and the Discomfort Questionnaire (DQ) were used as intervention instruments, which were adapted by Werner from the Corlett Diagram (CORLETT; MANENICA, 1980; WERNER et al., 2003). The data collection instruments include a questionnaire to assess the environment and the workstation; organization of the work and the business; and content of the work (PESSA, 2010), using a continuous $15 \mathrm{~cm}$ line with two anchors at the ends ("dissatisfied" and "satisfied"). The example of the questionnaire was illustrated in Figure 1. 
Figure 1 - Example of the questionnaire

- Check the scale of your opinion on the following questions:

1. Temperature in your work environment

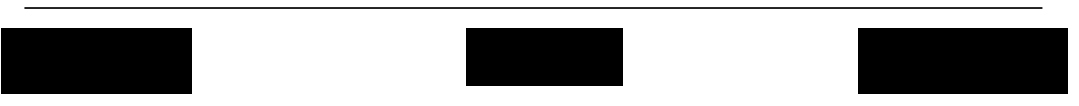

2. Noise in your work environment
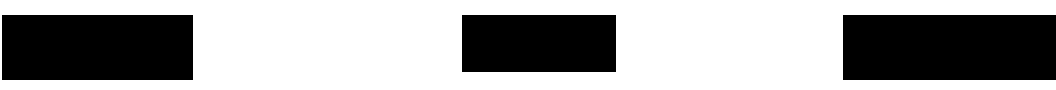

3. Lighting in your work environment

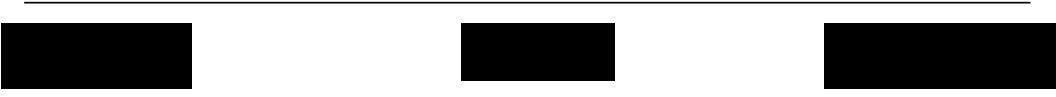

4. Vibrations in your work environment
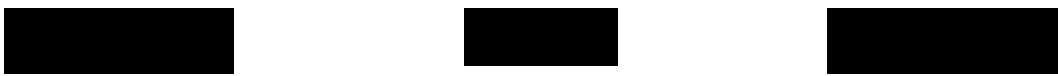

Source: Own authorship (2016)

One of the possible techniques to assess pain in the body is the judgment of the workers themselves, their personal evaluation in respect to the work (CORLETT; MANENICA, 1980; BALLARDIN; GUIMARÃES, 2009). Therefore, in sequence, from a diagram with the body parts, the workers indicated the areas of major discomfort using a continuous $9 \mathrm{~cm}$ scale with two anchors at the points "none" and "extreme" (CORLETT; MANENICA, 1980; WERNER et al., 2003).

The company in which the data was collected is an animal feed company located in southern Brazil. The company, excluding the administrative sector and human resources, can be divided into the following sectors: unloading, production, loading and maintenance.

Of a group of 100 workers, the participants were selected by availability; that is, by their free adherence to participate in the research. Workers on vacation, work leave, and those engaged in external activities were excluded from the study. The analyzed group consisted of 71 workers out of a total of 100 employees, with nine in the loading sector, four in the unloading sector, nine in maintenance and 49 in the production sector.

The workers participated in the research according to their respective shifts. Some general data were collected, such as age, height, weight, shift, time with the company and time in the sector. Two questions related to physical and mental fatigue were also added.

The data were initially analyzed by means of descriptive statistics. Then the Analysis of Variance (ANOVA) was used to investigate and identify the most critical factors related to the workload. The use of ANOVA at a significance level of $5 \%$ was justified by its robustness as a statistical test and little to no violation of assumptions for its use (normality and homoscedasticity). 
From the expert opinion, and using the Least Significant Differences (LSD) Intervals of the Fisher method as the discriminant, the responses of the workers were analyzed in groups of satisfied and dissatisfied, thus instructing the proposed analysis.

\section{RESULTS}

\section{PROFILE OF THE WORKERS AND DESCRIPTION OF THE SECTORS' ACTIVITIES}

The research was conducted in 4 sectors of the company, with the participation of 71 workers, $95 \%$ being male, with a mean (M) of 35.9 years of age and a standard deviation (s) of 11.2 years. The average time each worker spent in his/her position is 7.15 years, $s=5.05$, while the mean time with the company was 8.46 years, $s=5.67$, demonstrating that the workers were with the company for longer than their time in their particular position, possibly being moved to other functions in the company. The data relative to the schooling of the workers revealed that: $7 \%$ have a complete or incomplete college education; $67 \%$ have a complete or incomplete high school education; and $26 \%$ have a complete or incomplete primary school education.

The following is a description of the activities developed in the sectors of the company studied.

In the unloading sector, the unloading of raw materials takes place, where the workers unload the materials from the truck onto a conveyor belt. Then, the products are made into blocks according to their classification and, when used, are placed on a conveyor belt that transports them to the elevator. The main products are feather meal, blood meal, poultry meal, canola, wheat, corn, sorghum and rice.

The production sector is where various kinds of feed are manufactured, meeting a large demand. Packaging, stitching and bagging machines can be found in this sector, as well as two extruders and several elevators for transporting both raw materials and finished products. Production assistants work in this sector, transporting the feed to the conveyor belts, as well as operators of machines such as extruding, stitching and bagging machines on the first floor and a pelletizing machine on the second floor. The process takes place as follows: the raw material elevators transport the feed from the unloading area to the storage silos. From there the product is transported through a screw conveyor to the scales where it is weighed. Following this, the product is transported by an elevator to the mills, which, after the product is milled, it is mixed, added to a premix and sent through elevators to its final destination. If they are extruded products, which are products cooked with high pressure and presented in different shapes and sizes, they go to the extruders. If the products are to be pelletized, that is, the food is compressed and presented in the form of tablets, they go to the pelletizer and are then bagged. The process was illustrated in figure 2 . 
Figure 2 - Flowchart describing the industrial process

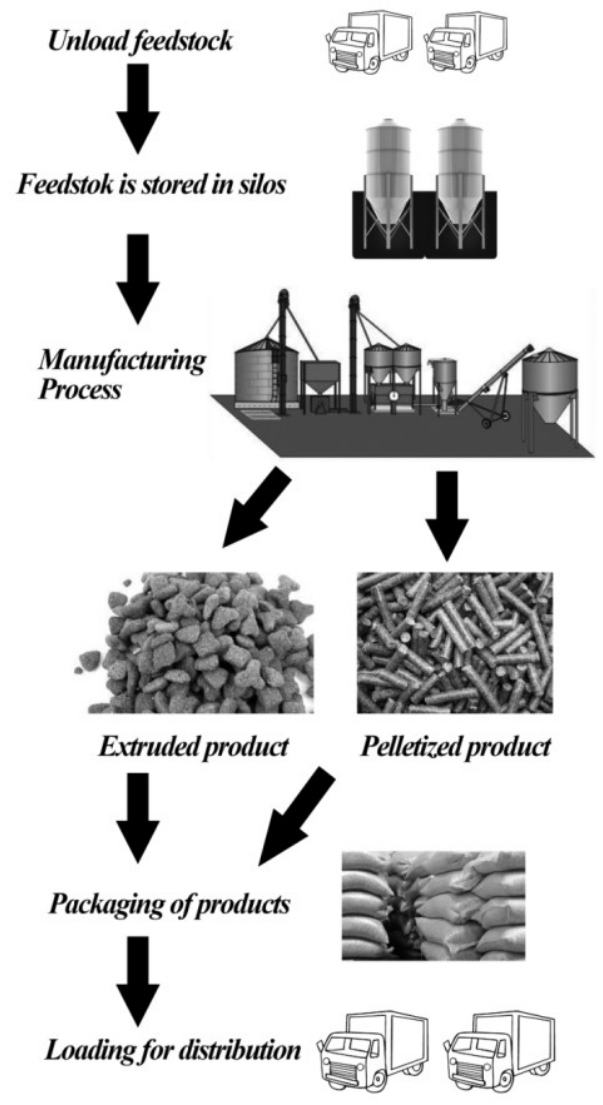

Source: Own authorship (2016)

The loading sector is responsible for loading the trucks. The feed that has completed production is transported by conveyor belts to the block making area and is blocked. From there, as the load order is requested it is loaded into the truck through a conveyor belt which is manually loaded.

The maintenance sector is the sector responsible for carrying out repairs when necessary, be they corrective, preventative, mechanical or electrical. The most common mechanical repairs in the company are cutting metal sheets for manufacturing or reforming parts, welding and general machine repairs. Electrical repairs include machine maintenance, the assembly of drives, programming equipment such as frequency inverters and soft starters, and installation and maintenance of light fixtures, among other things.

\section{MACROERGONOMIC WORK EVALUATION}

The results of the questionnaire about the demands of Macroergonomic Design (FOGLIATTO; GUIMARÃES, 1999), are contained in Table 1. The results were collected from a continuous $15 \mathrm{~cm}$ scale, with two anchors at the ends ("dissatisfied" and "satisfied"). 
Table 1 - Results of the Questionnaire of Demands, with a continuous $15 \mathrm{~cm}$ scale

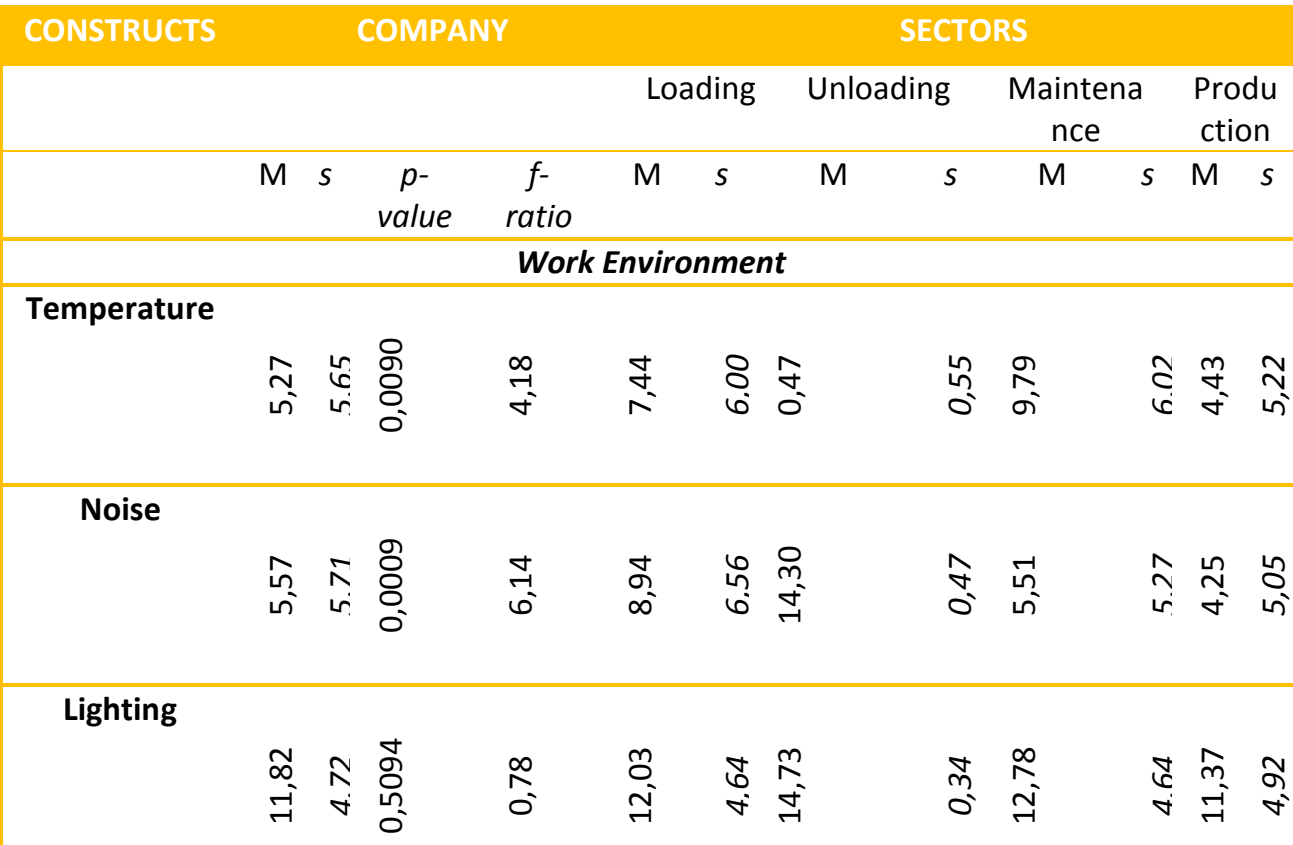

Workstation Evaluation

Aerodispersoi

ds

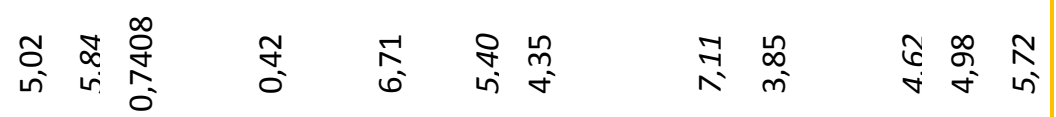

Posture

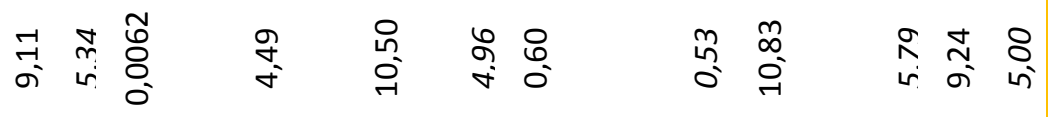

Vibrations

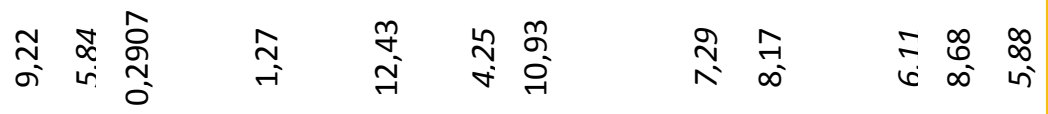

Workspace

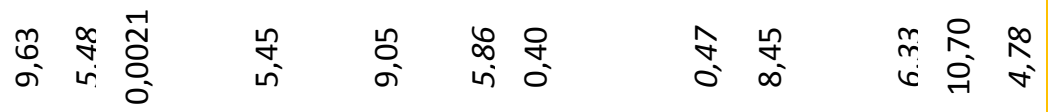

Quality of

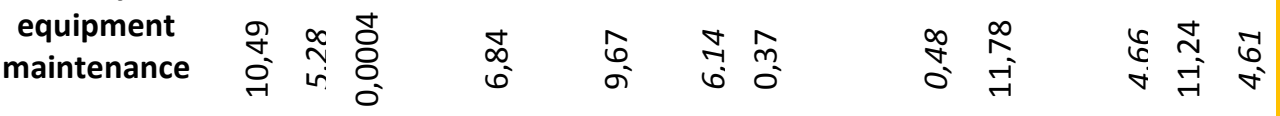

Workstation

\begin{tabular}{|c|c|c|c|c|c|}
\hline $\begin{array}{lll}n & 8 & 0 \\
0 & 8 & 8 \\
-1 & \text { in } & 0 \\
0\end{array}$ & $\begin{array}{l} \pm \\
\vdots \\
0 \\
0\end{array}$ & \begin{tabular}{l}
\multirow{N}{*}{} \\
Oे
\end{tabular} & 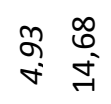 & 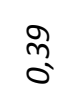 & $\begin{array}{l}\vec{f} \\
\sigma\end{array}$ \\
\hline
\end{tabular}


Work Organization

\begin{tabular}{|c|c|c|c|c|c|c|c|c|c|c|c|c|}
\hline $\begin{array}{l}\text { Number of } \\
\text { employees to } \\
\text { perform a } \\
\text { task }\end{array}$ & $\begin{array}{l}\widetilde{1} \\
\text { ㅇ. }\end{array}$ & $\begin{array}{l}\infty \\
\infty \\
\dot{1}\end{array}$ & $\begin{array}{l}\text { 옹 } \\
8 \\
0 \\
0\end{array}$ & $\begin{array}{l}\mathscr{b} \\
\emptyset \\
\emptyset\end{array}$ & $\underset{\sim}{\stackrel{\overbrace{}}{\sim}}$ & $\begin{array}{l}\hat{\infty} \\
\stackrel{\sim}{v}\end{array}$ & $\underset{\sim}{\stackrel{\infty}{\sim}}$ & $\begin{array}{l}\tilde{m} \\
\sigma^{\prime}\end{array}$ & જ્ & $\begin{array}{l}\text { in } \\
\text { in }\end{array}$ & $\begin{array}{r}\stackrel{-1}{\hat{~}} \\
\text { ตे }\end{array}$ & $\begin{array}{l}\text { ర్ } \\
\text { (n) }\end{array}$ \\
\hline \multicolumn{13}{|l|}{ Breaks } \\
\hline & $\begin{array}{l}\underset{+}{+} \\
\underset{\sim}{\sim}\end{array}$ & $\begin{array}{l}6 \\
n \\
n\end{array}$ & $\begin{array}{l}\underset{N}{N} \\
\stackrel{n}{0}\end{array}$ & $\stackrel{m}{\stackrel{n}{\sigma}}$ & 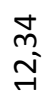 & $\begin{array}{l}\text { ने } \\
\text { m }\end{array}$ & $\begin{array}{l}\infty \\
\stackrel{m}{\sim} \\
\underset{\sim}{+}\end{array}$ & $\stackrel{\infty}{\stackrel{\infty}{\sigma}}$ & $\begin{array}{l}\mathscr{q} \\
\stackrel{\sim}{\sim}\end{array}$ & $\begin{array}{r}\tilde{n} \\
\nabla\end{array}$ & $\underset{\sim}{\stackrel{\sim}{\sim}}$ & $\begin{array}{l}\tilde{b} \\
m\end{array}$ \\
\hline
\end{tabular}

Days off

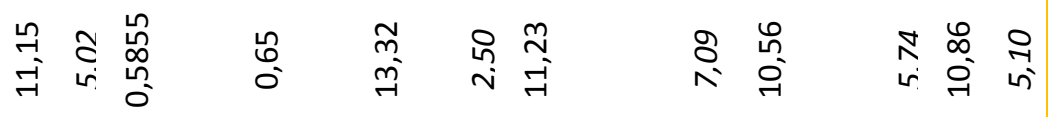

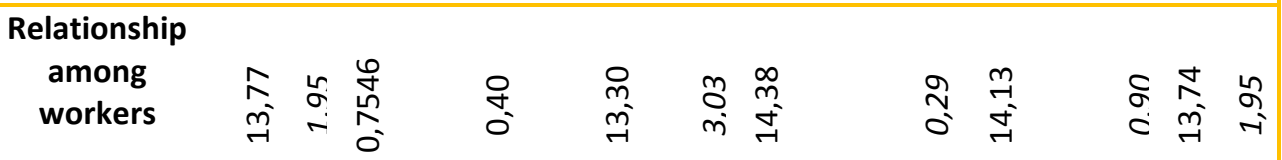

\begin{tabular}{|c|c|c|c|c|c|c|c|c|c|}
\hline $\begin{array}{l}\text { Attending to } \\
\text { suggestions }\end{array}$ & $\stackrel{\text { ஸn }}{\stackrel{0}{\sigma}}$ & \begin{tabular}{ll}
$\infty$ & \multicolumn{1}{c}{} \\
$\sim$ & 8 \\
in & 0 \\
0
\end{tabular} & $\begin{array}{l}\infty \\
0^{-} \\
\infty\end{array}$ & $\begin{array}{l}\text { f } \\
\text { g- }\end{array}$ & $\begin{array}{ll}\stackrel{P}{m} & R \\
\sim & 0\end{array}$ & 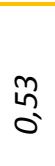 & ஜे & 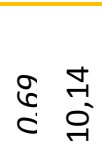 & $\begin{array}{l}\text { L } \\
\text { ni }\end{array}$ \\
\hline \multicolumn{10}{|l|}{ Pace of work } \\
\hline & $\begin{array}{l}-1 \\
\infty \\
0 \\
0\end{array}$ & $\begin{array}{l}\wedge \\
\infty \\
\infty\end{array}$ & 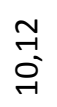 & $\begin{array}{l}\hat{\infty} \\
\hat{\sigma}\end{array}$ & 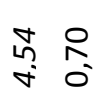 & $\begin{array}{l}0 \\
\mathfrak{L}^{2} \\
0\end{array}$ & 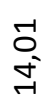 & 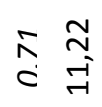 & $\stackrel{\circ}{\sim}$ \\
\hline
\end{tabular}

Work Content

Physical

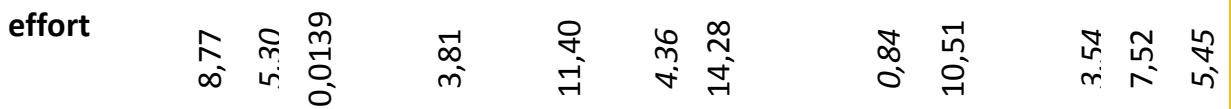

Mental effort

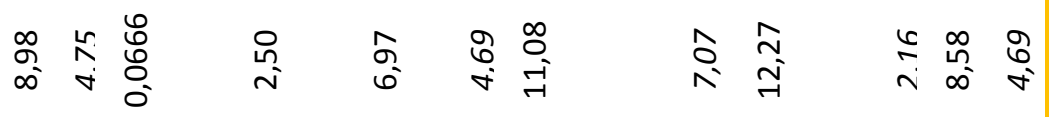

Monotony

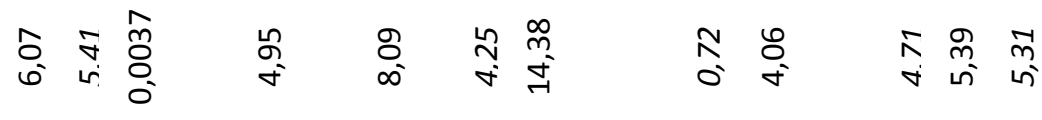




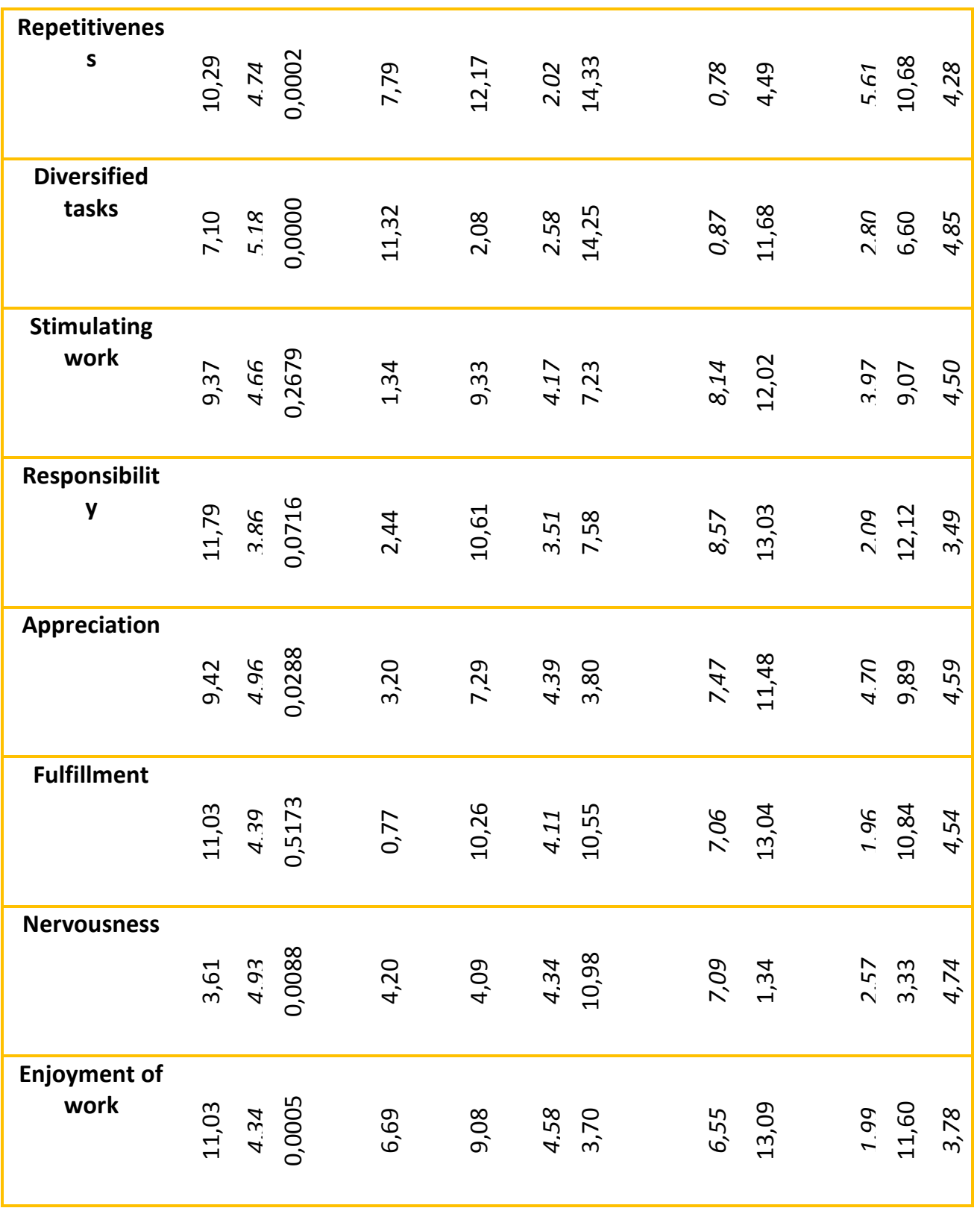

Source: Own authorship (2016)

\section{Environment and Workstation}

The first factor assessed was environment and workstation. From the demands questionnaire, the 71 workers responded regarding their level of satisfaction with the environment. Dissatisfaction was noted among the workers with respect to temperature $(M=5.27$ and $s=5.65)$ and noise $(M=5.57$ and $s=5.71)$ in the work environment. On the other hand, the workers showed satisfaction with the lighting $(M=11.82$ and $s=4.71)$.

It was possible to demonstrate that the variables that lead to dissatisfaction are noise and temperature, while the lighting variable indicates satisfaction of the workers. 
When investigating the perception of temperature by analysis of variance at a significance level of $5 \%$, it was shown that there is a statistical significance among the sectors $(p=0.0090$ and $F=4.18)$.

In the unloading sector $(M=0.47$ and $s=0.55)$ there was greater dissatisfaction with the temperature, which, along with the production sector $(M=4.43$ and $s=5.22)$, formed the group of workers most dissatisfied with the temperature. The loading sector $(M=7.44$ and $s=6.00)$ showed moderate dissatisfaction, being close to the evaluation center (maximum of 15), thereby forming the second group. In turn, the maintenance sector ( $M=9.79$ and $s=6.02$ ) had the best evaluation, forming the group of workers most satisfied with the illumination.

As for the evaluation of the workers' satisfaction level regarding noise in the work environment, by analysis of variance at a significance level of $5 \%$, it was shown that there is a statistical significance among the sectors $(p=0.0009$ and $F=6.14)$.

When analyzing the sectors, it was found that the noise variable caused greater dissatisfaction in the production $(M=4.25$ and $s=5.05)$ and maintenance $(M=5.51$ and $s=5.27)$ sectors. The loading sector $(M=8.94$ and $s=6.56)$ presented a good level of satisfaction. Finally, the unloading sector $(M=14.3$ and $s=0.47)$ showed high levels of worker satisfaction.

The results of the lighting of the work environment of the company $(M=11.81$ and $s=4.71)$, by analysis of variance at a significance level of $5 \%$, showed that there was no statistical significance among the sectors $(p=0.5094, F=$ 0.78 .

\section{Workstation Evaluation}

The perception of the workers as to their workstations indicated that there are two groups of factors: first, the presence of aerodispersoids (dust) ( $M=5.02$ and $s=5.84$ ) in the workstation was the factor responsible for forming the dissatisfied group of workers. The other group was formed by the factors that the workers were satisfied with, including posture $(M=9.11$ and $s=5.34)$, vibration $(M=9.22$ and $s=5.84)$, the workspace $(M=9.63$ and $s=5.48)$, the quality of equipment maintenance $(M=10.49$ and $s=5.28)$, and the workstation $(M=10.63$ and $s=5.00$ ). LSD (Least Significant Differences) intervals of the Fisher method were used as the discriminant for the formation of the groups.

The investigation of the perception of the presence of dust showed that there is no statistical significance among the sectors $(p=0.7408, F=0.42)$.

In the evaluation of satisfaction regarding work postures, by analysis of variance at a significance level of $5 \%$, a difference was shown among the sectors $(p=0.0062, F=4.49)$. Two groups were formed: the production sector $(M=9.24$ and $s=5.00)$, loading sector $(M=10.5$ and $s=4.96)$ and maintenance sector $(M=10.83$ and $s=5.79)$ comprised the group of workers that were satisfied with the work posture; the unloading sector $(M=0,6$ and $s=0,53)$ comprised the dissatisfied group of workers. 
In the analysis of the perception of vibration $(M=9.22$ and $s=5.84)$, by analysis of variance at a significance level of $5 \%$, no statistical significance was found among the sectors $(p=0.2907, F=1.27)$.

The evaluation of the workspace, by analysis of variance at a significance level of $5 \%$, showed that there is a statistical significance among the sectors $(p=0.0021, F=5.45)$. Two groups were observed. The first was formed by the unloading sector ( $M=0.4$ and $s=0.47)$, where was a high degree of dissatisfaction. The workers were satisfied in the second group, comprised of the maintenance $(M=8.45$ and $s=6.33)$, loading $(M=9.05$ and $s=5.86)$ and production $(M=10.70$ and $\mathrm{s}=4.78$ ) sectors.

In the investigation of the quality of equipment maintenance, by analysis of variance at a significance level of $5 \%$, a statistical significance was found among the sectors $(p=0.0004, F=6.84)$. In the analysis of equipment maintenance, the unloading sector $(M=0.37$ and $s=0.48)$ formed the dissatisfied group of workers. The loading $(M=9.67$ and $s=6.14)$, production $(M=11.24$ and $s=4.61)$ and maintenance $(M=11.78$ and $s=4.66)$ sectors formed the group that was satisfied with the quality of equipment maintenance.

When investigating the satisfaction with the workstation by sector $(M=10.63$ and $s=5.00)$, by analysis of variance at a significance level of $5 \%$, no statistical significance was shown among the sectors $(p=0.0004, F=6.84)$.

\section{Work Organization}

The third factor evaluated was work organization. From the questionnaire of demands, the 71 workers responded regarding their level of satisfaction with work organization. It was noted that there were not any factors that caused general dissatisfaction among the workers. The number of employees to perform the activities ( $M=8.02$ and $s=5.81)$ is the variable having less satisfaction among the workers, but it can still be considered a regular level of satisfaction. Regarding attending to suggestions $(M=10.25$ and $s=5.18)$, the pace of work $(M=10.25$ and $s=5.18)$ and days off (weekly rest) $(M=11.15$ and $s=5.02)$, these variables characterized the group of satisfied workers. The variables breaks $(M=12.41$ and $s=3.56)$ and relationship among workers $(M=13.77$ and $s=1.95)$ indicated very satisfied individuals.

When evaluating the number of employees to perform the tasks, statistical differences were found among the sectors $(p=0.0005 F=6.66)$. Using LSD intervals, two homogeneous groups were formed, and the production sector $(M=9.71$ and $s=5.61)$ comprised the workers that were satisfied with the number of employees. On the other hand, the unloading ( $M=0.27$ and $s=0.32)$, loading $(M=4.27$ and $s=2.87)$ and maintenance $(M=5.99$ and $s=5.55)$ sectors formed the unsatisfied group of workers.

Another variable assessed was the handling of suggestions and requests of the workers. By analysis of variance with a significance level of $5 \%$, a statistical significance was found among the sectors. The dissatisfied group was characterized by the unloading sector $(\mathrm{M}=0.7$ and $\mathrm{s}=0.53)$. On the other hand, there was a high level of satisfaction by the workers in production $(M=10.14$ and $s=5.05)$, loading $(M=11.47$ and $s=4.30)$ and maintenance $(M=13.9$ and $s=0.69)$. 
The investigation of work pace pointed out that there is a statistical difference between the sectors $(p=0.0000 F=10.12)$. Again the unloading sector showed an elevated level of dissatisfaction ( $M=0.7$ and $s=0.56)$, while the loading $(\mathrm{M}=9.86$ and $\mathrm{s}=4.54)$, production $(\mathrm{M}=11.22$ and $\mathrm{s}=4.50)$ and maintenance $(M=14.01$ and $s=0.71)$ sectors were classified as satisfied.

In the analysis of days off and weekly rest $(M=11.15$ and $s=5.02)$, the investigation found that there was no statistical significance ( $p=0.5955 \quad F=0.65$ ) among the sectors. The group of four sectors is at a level of satisfaction $(M=11.15$ and $s=5.02$ ).

Break time (including lunch and snacks) is another factor in which the workers showed a high level of satisfaction ( $M=12.41$ and $s=3.56)$. By analysis of variance with a significance level of $5 \%$, no statistical significance was found among the sectors ( $p-0.7325 \mathrm{~F}=0.43)$.

The relationship among the workers in each sector $(M=13.77$ and $s=1.95)$ did not show statistical significance among the sectors, by analysis of variance at a significance level of $5 \%(p=0.7546 \mathrm{~F}=0.40)$.

\section{Work Content}

The general perception of physical and mental fatigue among the sectors was moderate. In the investigation of this perception among the sectors, differences in the perception of physical effort were observed among them $(p=0.0139$ and $F=3.81)$. Using LSD intervals of the Fisher method, 02 homogeneous groups were found.

The maintenance sector can be added to the production sector. However, there is a tendency for this sector to belong to the group formed together with the loading and unloading sectors. From this, it can be concluded that the employees of the production sector have a lesser perception of physical effort than the other three sectors.

When investigating the perception of mental effort among the sectors, it was observed that there were no differences in this perception among them $(p=0.066$ and $\mathrm{F}=2.5$ ).

In the production sector, the workers classified the physical effort ( $M=7.52$ $s=5.45)$ necessary for their work as moderate, unlike the other sectors, which had a perception of greater physical effort (maintenance $(M=10.51$ and $s=3.54)$, loading $(M=11.4$ and $s=4.35)$ and unloading $(M=14.27$ and $s=0.84))$. On the other hand, production workers did not indicate a high demand of mental effort $(\mathrm{M}=8.58$ and $\mathrm{s}=4.69)$, a fact similar to the loading sector $(\mathrm{M}=6.97$ and $\mathrm{s}=4.69)$. As for the unloading ( $M=11.07$ and $s=7.07)$ and maintenance $(M=12.27$ and $s=2.15)$ sectors, the mental effort was more present.

The group of workers that work in maintenance $(M=4.05$ and $s=4.71)$, production $(M=5.39$ and $s=5.31)$ and loading $(M=8.09$ and $s=4.25)$ do not view their activities as monotonous. However, in the unloading sector, there was a very high rate of monotony ( $M=14.37$ and $s=0.72$ ).

In the analysis of the repetitiveness of work content, only in the maintenance sector $(M=4.49$ and $s=5.61)$ did the workers not consider the work repetitive. For 
the production $(\mathrm{M}=10.68$ and $\mathrm{s}=4.28)$, loading $(\mathrm{M}=12.17$ and $\mathrm{s}=2.02)$ and unloading ( $M=14.32$ and $s=0.78$ ) sectors, a high perception of repetitiveness was found. Given this context, the perception of the diversity of tasks was low in the loading $(M=2.07$ and $s=2.57)$ and production $(M=6.60$ and $s=4.85)$ sectors, and high in the maintenance $(M=11.68$ and $s=2.80)$ and unloading $(M=14.25$ and $s=0.87$ ) sectors.

The work was considered stimulating by the workers $(M=9.06$ and $s=4.50)$, with no statistical significance among the sectors $(p=0.26 \mathrm{~F}=1.34)$. The workers in the unloading sector $(M=7.57$ and $s=8.57)$ feel that their work does not involve much responsibility, while in the other sectors, the level of responsibility of work was recognized - loading $(M=10.61$ and $s=3.51)$, production $(M=12.12$ and $\mathrm{s}=3.49)$ and maintenance $(\mathrm{M}=13.03$ and $\mathrm{s}=2.09)$.

The results also show that in the unloading sector ( $M=3.8$ and $s=7.47)$, the workers did not consider themselves valued. The opposite situation is the case for the workers in loading ( $M=7.29$ and $s=4.38)$, production ( $M=9.89$ and $s=4.59)$ and maintenance. $(M=11.48$ and $s=4.70)$. When addressing the subject of autonomy, the workers formed a homogeneous group that emphasizes high autonomy in carrying out their work ( $M=11.03$ and $s=4.39)$.

The maintenance $(M=1.34$ and $s=2.56)$, production $(M=3.33$ and $s=4.73)$, and loading $(M=4.09$ and $s=4.34)$ workers reported no feelings of nervousness. However, in unloading ( $M=10.97$ and $s=7.08)$ the feeling of nervousness was very much present.

The unloading sector ( $M=3.7$ and $s=6.54)$ also indicated that the workers did not like their job. The opposite occurs with loading $(M=9.08$ and $s=4.58)$, production ( $M=11.60$ and $s=3.78)$ and maintenance $(M=13.09$ and $s=1.99)$, in which the workers claimed to like their work.

\section{Discomfort and/or Pain in parts of the body}

In the analysis of the company, there was not a high rate of complaints of discomfort among the employees. The overall mean was 0.46 and $s=1.33$, showing that there were not many complaints associated with these factors. The results are shown in Table 2.

Table 2 - Results of the Corlett Diagram with a continuous $9 \mathrm{~cm}$ scale

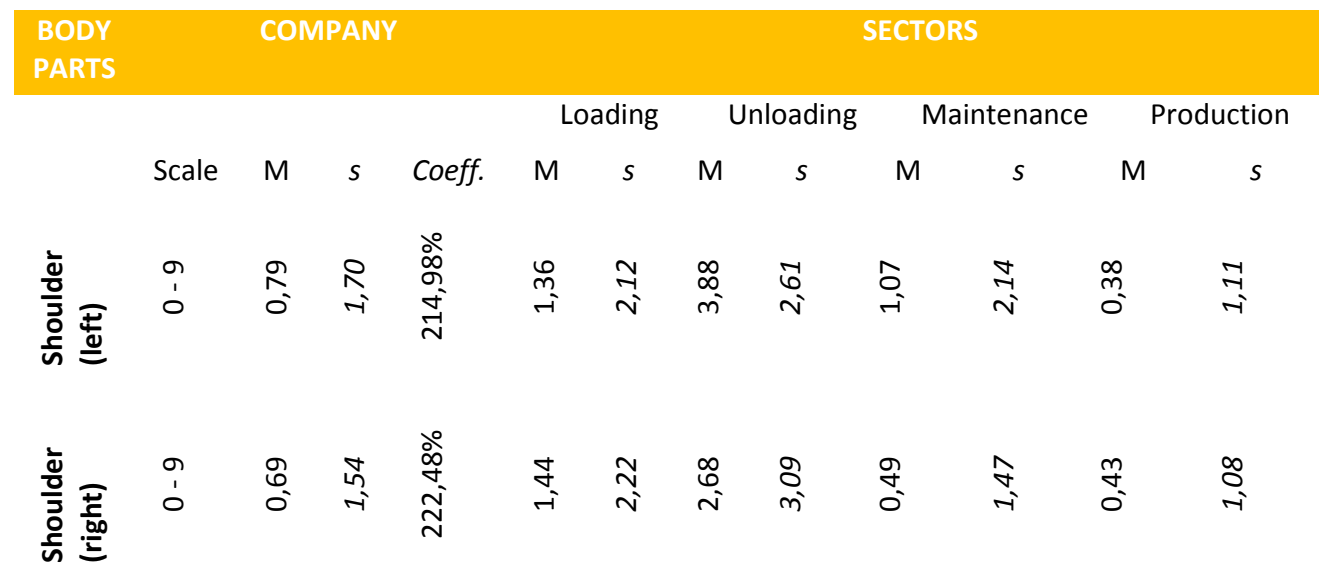




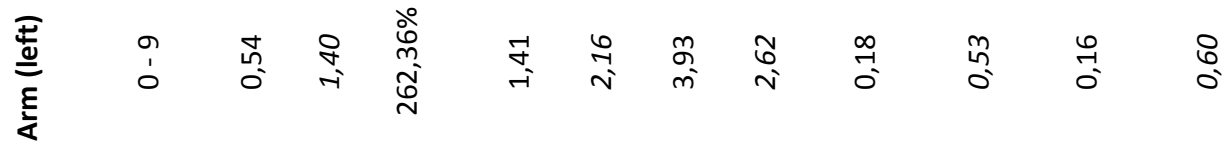

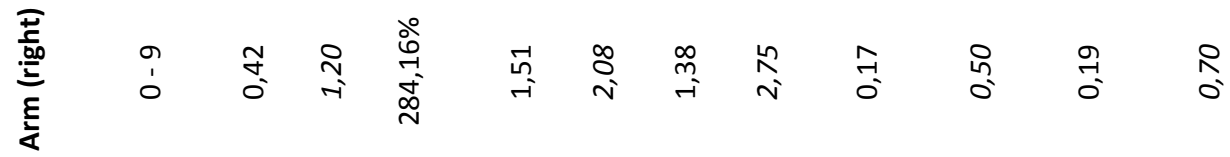

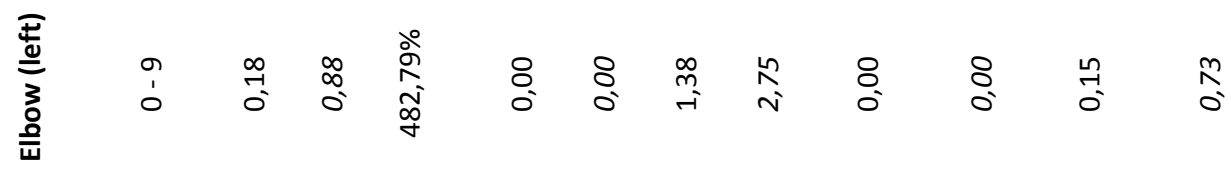

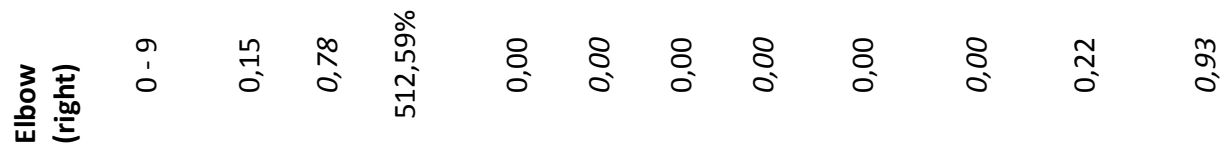

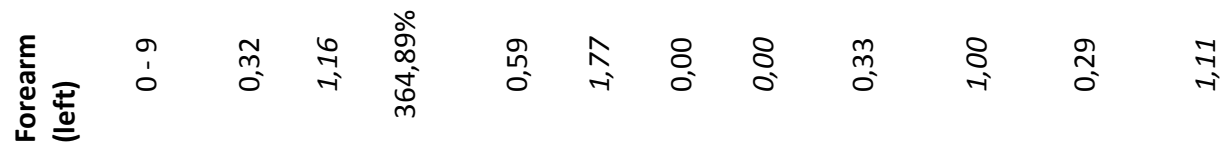

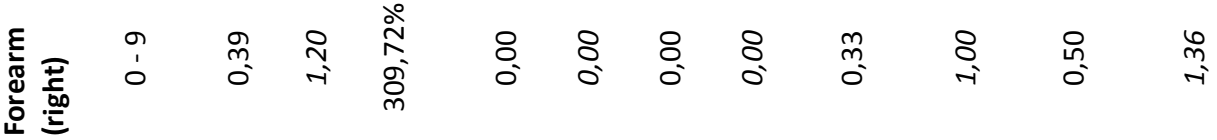

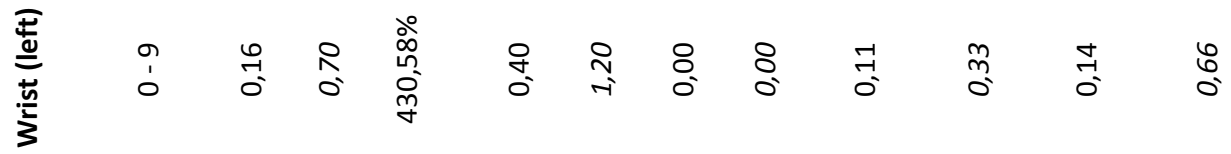

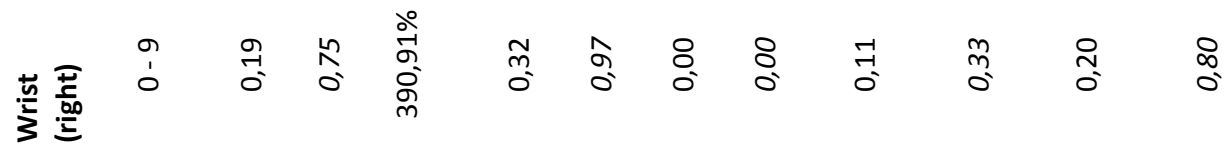

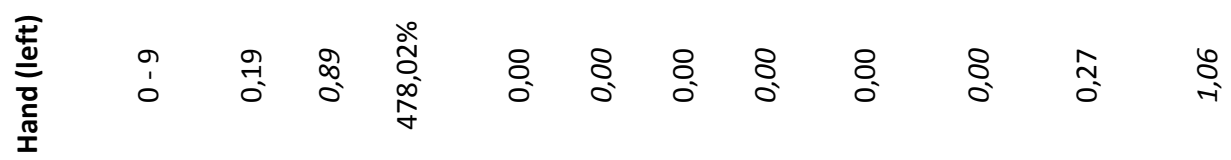

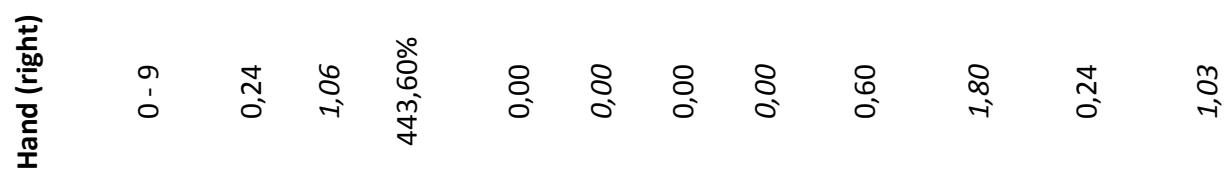

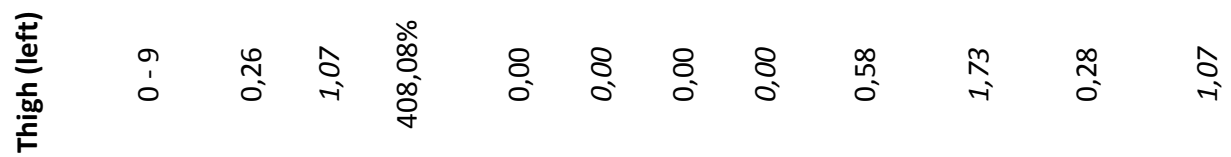

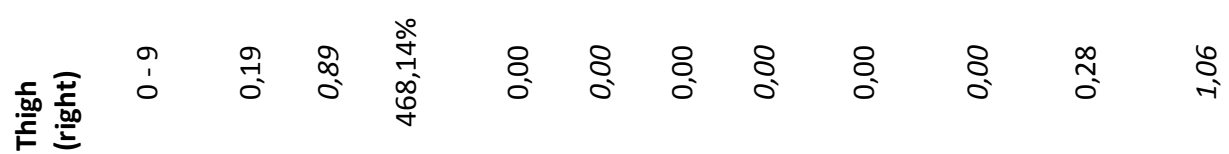




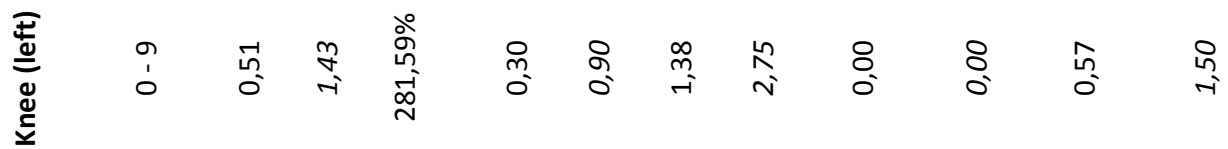

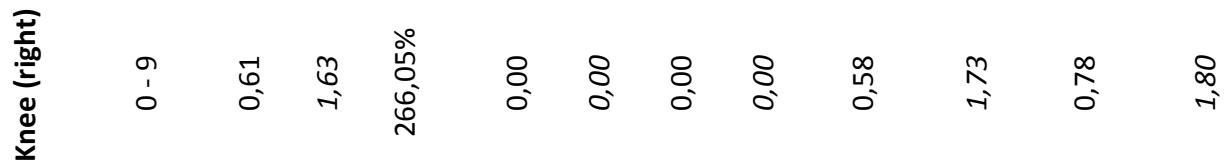

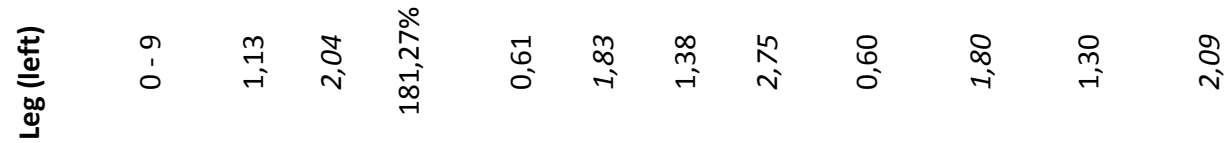

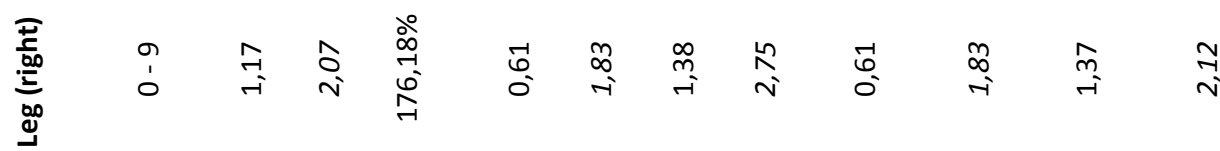

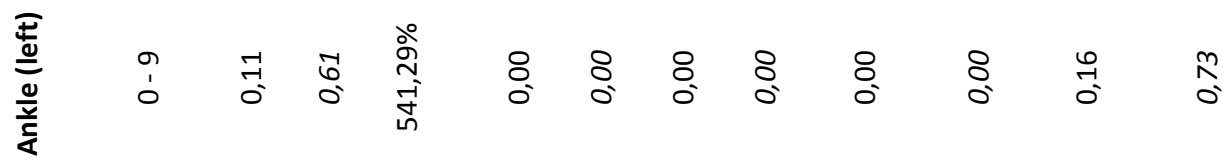

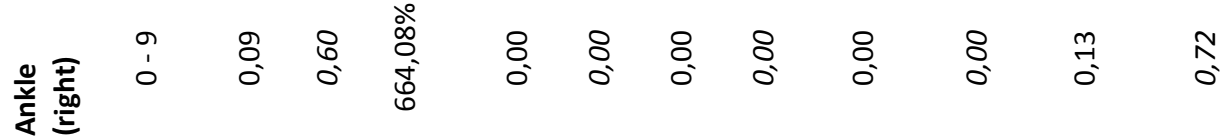

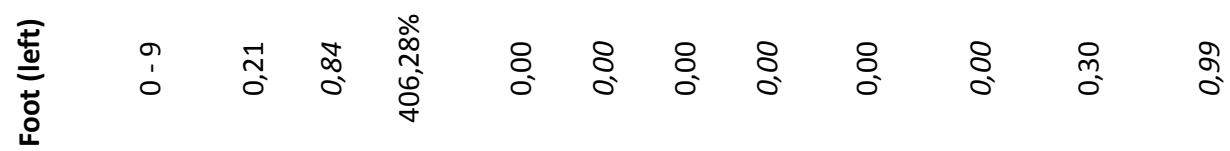

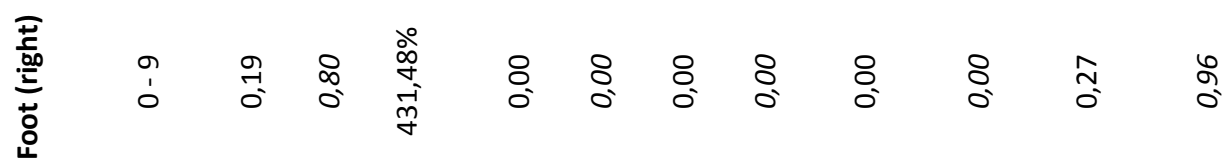

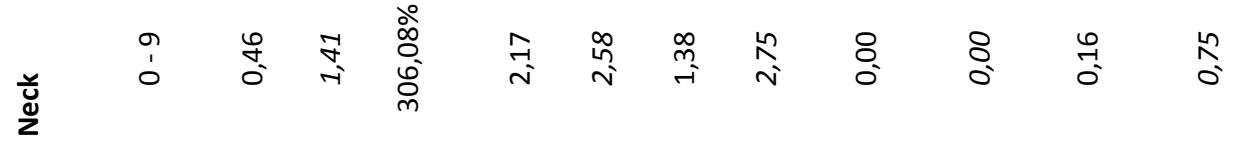

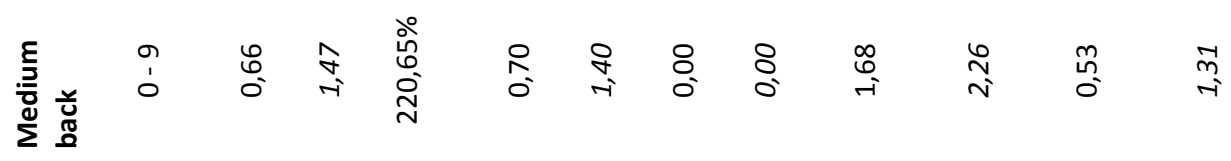

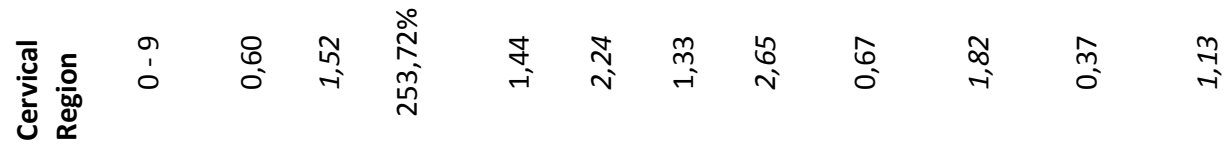

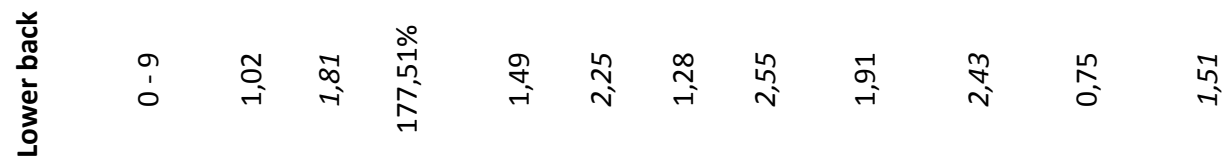




\begin{tabular}{|c|c|c|c|c|c|c|c|c|c|c|c|}
\hline $\begin{array}{l}\text { ํㅓㅇ } \\
\text { م) } \\
\frac{1}{0} \\
\frac{0}{2}\end{array}$ & $\begin{array}{l}\text { a } \\
1 \\
0\end{array}$ & $\stackrel{\infty}{\circ}$ & જ્ & $\begin{array}{l}\stackrel{\circ}{\text { m} ~} \\
\stackrel{-}{\circ} \\
\stackrel{\infty}{-}\end{array}$ & $\underset{N}{\sim}$ & $\begin{array}{l}\emptyset \\
\sim\end{array}$ & m & $\begin{array}{l}8 \\
\text { v }\end{array}$ & $\underset{\stackrel{\sim}{\sim}}{-}$ & $\underset{N}{N}$ & $\begin{array}{l}\frac{9}{10} \\
0\end{array}$ \\
\hline$\frac{n}{2}$ & $\begin{array}{l}0 \\
1 \\
0\end{array}$ & స్ & ঠे & 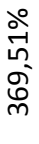 & $\begin{array}{l}8 \\
\text { ○' }\end{array}$ & $\begin{array}{l}\text { ○ } \\
\text { ○' }\end{array}$ & $\begin{array}{l}8 \\
\text { ○' }\end{array}$ & $\begin{array}{l}8 \\
\text { ᄋ' } \\
\text { o' }\end{array}$ & $\begin{array}{l}\text { ఠ̆ } \\
\text { ○' }\end{array}$ & $\underset{-1}{N}$ & $\begin{array}{l}\text { m } \\
\text { o' }\end{array}$ \\
\hline
\end{tabular}

Source: Own authorship (2016)

However, even without high levels of pain or discomfort, the investigation of these factors was carried out among the sectors. In loading, a difference was found among the parts of the body $(p=0.0004, F=2.33)$, with some discomfort in the right $\operatorname{arm}(\mathrm{M}=1.51$ and $\mathrm{s}=2.08)$, neck $(\mathrm{M}=2.16$ and $\mathrm{s}=2.58)$ and upper back $(\mathrm{M}=2.22$ and $\mathrm{s}=2.66)$, on a continuous $9 \mathrm{~cm}$ scale.

In the loading sector, there was also a statistical difference among the parts of the body ( $p=0.0406$ and $F=1.67$ ). The group of regions affected with some pain or discomfort was formed by the right shoulder $(M=2.675$ and $s=3.09)$, left shoulder ( $M=3.875$ and $s=2.61)$ and left arm $(M=3.925$ and $s=2.62)$.

The maintenance sector presented differences among the parts of the body $(p=0.0620$ and $F=1.49)$. The most affected region was the back, on account of the results of the upper back ( $M=1.42$ and $s=2.21)$, middle back $(M=1.68$ and $s=2.26)$ and lower back $(M=1.91$ and $s=2.43)$.

Finally, in the production sector, the analysis of variance also confirmed variability among the parts of the body ( $p=0.0000$ and $F=3.55)$. By the evaluation of the LSD intervals, the group that presented some discomfort was formed by the left leg $(M=1.29$ and $s=2.08)$ and right leg $(M=1.36$ and $s=2.12)$.

\section{DISCUSSIONS}

The approach of the study was facilitated by the interest of the company in knowing the perceived demands of its workers. The greatest challenge was approaching the workers, as there was a necessity to reduce the participants' insecurity in a way that they could expose themselves genuinely and sincerely. This challenge was overcome exactly by the participative approach, presenting the projection thoroughly, explaining the tools to be used, and in what way they could understand the reasons for each question and how they could participate in the search of alterations and improvements in their work conditions and environment (CORNELLI; GUIMARÃES, 2012; BITENCOURT; GUIMARÃES, 2012; FOGLIATTO; GUIMARÃES, 1999).

From the opinion of experts, and based on the perceptions of the workers, comes the following discussion of the results obtained. The lighting of the workplace as a whole was evaluated positively by the workers, evidence that the present levels of lighting are adequate and should be maintained in the company. Providing good lighting is a technically viable task, even if some effort on the part of the organization is required (KROEMER; GRANDJEAN, 2005).

As for the noise, there was greater dissatisfaction among the production and maintenance workers. The production and maintenance sectors share the same 
workspace in many activities, and are therefore influenced by similar factors. The demands of maintenance work occur, for the most part, in the production area of the company, exposing the workers of these sectors to the same risks. It is important to note that noise can be considered any undesired sound (KROEMER; GRANDJEAN, 2005). As to the dissatisfaction with the noise, it was possible to associate this discomfort with activities performed near the hammer mill, high power exhaust fans and bucket elevators, equipment that generates high levels of noise.

Finally, the temperature more strongly affects the workers in the unloading and production sectors. In unloading, the workers are exposed to a high level of physical activity, requiring a lot of bodily movement. As for the staff that works in production, they were found to be more exposed to higher temperatures than in other production process environments. This is due to the fact that the company works with many starches and products that retain humidity, which reduces the circulation of air in proximity to the production process equimpment. The production process also uses heat transfer by steam drying the final products, another factor that can increase the temperature of the environment. In the loading sector, although the dissatisfaction was less than in the other sectors, there is also complaints about the temperature of the environment. lida points out that temperature is a factor that directly influences the performance of human labor (IIDA, 2005). This factor was believed to also be influenced by the physical demands of the sector, like the unloading sector, but it was mitigated due to good site conditions, namely, the building was constructed less than 10 years ago, and the space is equipped with flat floors and the presence of trolleys for transport.

As for the workstation, greater dissatisfaction was found in the workers regarding aerodispersoids. For the loading sector, the causes can be identified as the dust arising from the packaging of the finished products, since the workers are not in an outdoor area of the workplace, outside of the production and unloading areas. The type of aerodispersoids present in this sector are dirt particles that stick to the individual's skin, causing dissatisfaction. Still, the type of activity performed in loading prevents the use of masks. The presence of dust also caused dissatisfaction in the unloading sector, mainly on hotter days.

The presence of dust in the production sector directly affected the workers of this sector, as well as those in maintenance. Despite being within the levels recommended by the work safety standards, the presence of aerodispersoids is constant due to the production of pelleted products. Both the raw material and the finished product, when transported within the factory, create dust, and consequently, dissatisfaction in the workers. Due to the fact that the maintenance sector works in disassembling equipment for repairs, contact with dust is a constant.

Pessa (2010), in a study involving workers, shifts and chronotype, pointed out that the physical environment must be comfortable for everyone, including eliminating noise and aerodispersoid problems, as well as controlling the temperature of the workstation.

All of the sectors were satisfied with the vibrations of the workstation. From analysis of variance, it was found that the unloading sector showed dissatisfaction with the working posture, workspace, and the quality of 
maintenance of the equipment. The activities carried out by the unloading sector involve unloading raw materials in bulk or in bags. The dissatisfaction regarding the maintenance of equipment is mainly due to failure to replace the conveyor belts used to stack the piles. The dissatisfaction of the space was found in the locations of the bins, where it is narrow and difficult to access and move. Posture is sacrificed by the presence of scrapers (or brooms) in the trucks at the end of bulk loads, which requires a semi-bent position of the employee.

Regarding the organization of work, the workers indicated a good level of satisfaction in their relationship with their colleagues, days off and weekly rest, and breaks for snacks and lunch. It is worth noting that the organization of work must be done in such a way that allows everyone to do their jobs, taking advantage of their abilities, with a sense of self-realization (IIDA, 2005).

The number of employees performing the work caused dissatisfaction in the unloading, loading and maintenance sectors. This demand, mainly among the loading and unloading sectors, can be associated with individual loading by the workers. What occurs in the company is that there is a determined number of employees for a given volume of cargo. Increasing the number of employees will not increase the quantity of unloaded cargo nor products for loading, because the demand for supplies and the factory production will not increase. However, the presence of a greater number of employees to perform the same task would minimize the amount of weight carried individually throughout the day. Therefore, this satisfaction was associated not so much with the frequency of loading or unloading, but with the intensity of the weight in each task performed.

In maintenance, dissatisfaction with the number of employees may be related to both the age of the factory equipment (some over 20 years old) and the updating and installation of new equipment.

The unloading sector showed dissatisfaction in attending to requests and suggestions, as well as with the pace of work. Dissatisfaction regarding the pace of work was accredited to the fact that little technology is used in unloading. The predominant manual labor in unloading bulk or bagged supplies imposes a work pace on the workers of this sector which leaves them dissatisfied. Again, not due to the frequency, but because of the volume of effort needed in each task performed.

Finally, regarding the content of the work in the production sector, the group of workers in this sector did not view the activities as monotonous, given the mix or portfolio of products that the company produces, approximately 70 products, which allows for staying ahead of different production processes many times a month. Kroemer and Grandjean (2005) state that the lack of stimuli is one of the characteristics of a monotonous environment.

In this context, repetitiveness was present and perceived by the group, given the fact that the activity of the same process continuously repeats. The perception of diversification of activities, diagnosed between monotony and repetitive, demonstrated balance, as each time a product is changed, a new process starts, but if this process is very long, or a large batch, it becomes monotonous and repetitive.

The perception of this group of workers was that they were important to the company's core purpose, and this gives them a sense of stimulation and value. As 
the processes and equipment are known, there is no presence of nervousness during the execution of the tasks, as the group masters its activities. As a consequence, the analysis showed a good indication that the group likes their work.

The maintenance group is considered a specialized staff and of great importance to the production process. This resulted in a very satisfied view of their work, with low monotony and little repetitiveness, indicating that it is a diverse service which provides a lot of stimuli and challenges, and does not make the workers very nervous, as the recognition is greater than the pressure, resulting in a group that feels valued.

With respect to loading, the products are loaded through borderô (cargo manifest) in trucks, by teams under the leadership of a cargo leader, but a main characteristic of this group is that they are contract workers with no registration with the company. Monotony was present, as it is not continuous work and may have 2 to 3 trucks simultaneously, or only 1 , depending on the load for the day. It was considered repetitive because it is a seemingly neverending process of piles and stacking cargo without much diversification. The sense of appreciation and encouragement, if confused with the freedom to work or not, is due to lack of an employment bond, and the workers can choose which company they want to work with.

The unloading sector receives the raw material for manufacturing, which can come in sacks, bags or in bulk. These workers feel that their work is always the same, and those who work in unloading bulk products work only in this sector. The diversification lies in the type of raw material, bagged or in bulk, or the type of vehicle used for work. This group has a perceived responsibility of their service, but they do not feel very stimulated nor appreciated, for being a manual laborer is the most basic job in the factory, with a direct employment bond. Also, as the workers carry out very basic tasks, this causes them to not like their job, since they aim to rise to more specialized functions.

Finally, it is seen that the results obtained from the perception of the workers, in addition to the opinion of experts, allows the identification of a diagnosis of the company's situation. For this reason, it is emphasized that the collaborative participation of the workers in this process is important so that preventive and proactive activities can be implemented and have an effective result in maintaining the ability to work (CORNELLI; GUIMARÃES, 2012; BITENCOURT; GUIMARÃES, 2012; SCHMIDT; SJÖSTRÖM; ANTONSSON, 2015).

This study reinforced the efficiency of the Macroergonomic Work Analysis (MWA), since its use indicated facts that can improve working conditions, especially regarding the work project (GUIMARÃES et al., 2015). The Macroergonomic Design (MD), a tool used in the MWA, also showed effectiveness in identifying the ergonomic demand items, thus allowing the execution of the diagnosis.

\section{CONCLUSIONS}

This study allowed for an ergonomic assessment of an animal feed company. Through the application of the Macroergonomic Work Analysis (MWA), it was 
possible to diagnose the factors that cause dissatisfaction and satisfaction in the workers.

In general, there was satisfaction among the workers in several variables, although the cases of dissatisfaction deserve greater attention by the company. Some regions of the body of the workers experience discomfort, a fact that must be the object of a policy to prevent the risk of the incidence of diseases, such as Repetitive Strain Injury (RSI) and Work-related Musculoskeletal Disorders (WMSDs).

The study was limited to one of the phases of the ergonomic assessment method of the MWA, and the development of the other phases of the process is suggested for future works. With the participation of the workers, the diagnosis obtained in this study is able to serve as a basis for the development of a work project and instruct the implementation of an intervention program to address the demands identified.

The results obtained in this study cannot be generalized to all of the animal feed companies, mainly for those that use automated production processes. The Macroergonomic Work Analysis, introduced by Guimarães, explores a participative process totally influenced by the workers and their work environment, in such a way that for each new study, it is important to carry out a new application of the method. 


\title{
Análise ergonômica em uma indústria de alimentação animal: demandas e ambiente de trabalho
}

\begin{abstract}
RESUMO
A avaliação ergonômica do trabalho é uma ferramenta que visa o cuidado com a saúde do trabalhador e instruir a elaboração de um projeto de trabalho capaz de aumentar a produtividade da empresa. O objetivo foi realizar uma análise ergonômica de uma indústria de alimentação animal, baseada na percepção dos trabalhadores e opinião de especialistas em ergonomia. O estudo foi baseado na fase de apreciação ergonômica da Análise Macroergonômica do Trabalho (AMT), utilizando como ferramentas o método de Design Macroergonômico (DM) e do Questionário de Desconforto (QD). A percepção geral dos trabalhadores foi de satisfação com o ambiente, organização e conteúdo do trabalho. Algumas queixas foram relatadas quanto ao ruído $(M=5,57)$, temperatura $(M=5,27)$, e a presença de aerodispersóides no ambiente da indústria $(M=5,02)$. Na organização do trabalho os setores de descarga $(M=2,87)$, carregamento $(M=4,27)$ e manutenção $(M=5,99)$ apresentaram níveis de satisfação baixo quanto ao número de funcionários para realização das tarefas. Os trabalhadores relataram baixa percepção de desconforto $(M=0,46)$, contudo em cada setor houve alguma queixa de dor em determinadas partes do corpo. O estudo demonstrou que a dinâmica colaborativa dos trabalhadores, tal qual definido no método AMT, juntamente com a aplicação ferramentas DM e QD, foram eficientes na construção de um diagnóstico ergonômico para instruir um projeto de trabalho para a empresa.
\end{abstract}

PALAVRAS-CHAVE: Macroergonomia. Design Macroergonômico. Projeto de Trabalho. Desconforto. 


\section{REFERÊNCIAS}

BALLARDIN, L.; GUIMARÃES, L. B. M. Avaliação da carga de trabalho dos operadores de uma empresa distribuidora de derivados de petróleo. Production, v. 19, n. 3, p. 581-592, 2009. crossref

BITENCOURT, R. S.; GUIMARÃES, L. B. M. Macroergonomic analysis of two different work organizations in a same sector of a luminary manufacturer. Work, v. 41, n. 1, p. 2686-2694, 2012.

BRIDGER, R.S. Introduction to ergonomics: cognitive ergonomics problem solving and decision making. Nova York: McGraw-Hill; 1995:529. crossref

CAUCHICK, M. P. A. et al. Metodologia de pesquisa em engenharia de produção e gestão de operações. Rio de Janeiro: Elsevier: ABEPRO, 2012.

CORLETT, E. N.; MANENICA, I. The effects and measurement of working postures. Applied ergonomics, v. 11, n. 1, p. 7-16, 1980. crossref

CORNELLI R. Aplicação da AMT para a redução de perdas de matérias- primas e de custos ergonômicos: $O$ caso de uma empresa de componentes de calçados. Dissertação (Mestrado em Engenharia de Produção), Universidade Federal do Rio Grande do Sul, Porto Alegre, 2010.

CORNELLI, R.; GUIMARÃES, L. B. M. Macroergonomic intervention for work design improvement and raw materials waste reduction in a small footwear components company in Rio Grande do Sul-Brazil. Work, v. 41, n. 1, p. 56125620, 2012.

FOGLIATTO, F. S.; GUIMARÃES, L. B. M. Design macroergonômico de postos de trabalho. Produto \& Produção, Porto Alegre, v. 3, n. 3, p. 1-15, 1999.

GUIMARÃES, L. B. M. ; PESSA, S. L. R.; BIGUELINI, C. Analysis of the workload imposed on the workers of the imprint and cutting/welding sectors of a flexible packaging manufacturer. Work, v. 41, n. 1, p. 1647-1655, 2012.

GUIMARÃES, L. B. M. Ergonomia de Processo. 4a ed. Porto Alegre: FEENG Fundação Empresa Escola de Engenharia da UFRGS; 2002.

GUIMARÃES, L. B. M. et al. Participatory ergonomics intervention for improving human and production outcomes of a Brazilian furniture company. International Journal of Industrial Ergonomics, v. 49, p. 97-107, 2015. crossref 
IIDA, I. Ergonomia. Projeto e Produção. São Paulo: Editora Edgard Blucher, 2005.

KLEINER, B. M. Macroergonomics: analysis and design of work systems. Applied ergonomics, v. 37 , n. 1, p. 81-89, 2006. crossref

KROEMER, K. H.; GRANDJEAN, E. Manual de ergonomia: adaptando o trabalho ao homem. Porto Alegre: 5a Ed. Bookman Editora, 2005.

KURATA, Y. B.; BANO, R. M. L. P.; MATIAS, A. C. Effects of workload on academic performance among working students in an undergraduate engineering program. Procedia Manufacturing, v. 3, p. 3360-3367, 2015. crossref

LUZ, R. P. D.; LAPERUTA, D. G. P.; COSTA, S. E. G. D.; PESSA, S. L. R. Fatores Humanos \& Ergonomia sob a ótica da Visão Baseada em Recursos: O Capital Humano como fonte de vantagem competitiva sustentável. In XXII Simpósio de Engenharia de Produção; Bauru, SP. 2015.

MEHTA, R. K.; AGNEW, M. J. Effects of concurrent physical and mental demands for a short duration static task. International Journal of Industrial Ergonomics, v. 41, n. 5, p. 488-493, 2011. crossref

ORMELEZ, C. R.; ULBRICHT, L. Análise ergonômica do trabalho aplicada a um posto de trabalho com sobrecarga física. Revista Uniandrade, v. 11, n. 2, p. 6984, 2013. crossref

PEGATIN, T.O. et al. A ergonomia como fator econômico e competitivo para pequenas empresas. Revista Gestão Industrial, v. 4, n. 03, p. 133-145, 2008. crossref

PESSA, S. L. R. Análise do trabalho nos três turnos do setor de corte e solda e impressão de uma indústria de embalagens plásticas flexíveis de alimentos, considerando o cronotipo do trabalhador. Tese (Doutorado em Engenharia de Produção), Universidade Federal do Rio Grande do Sul, Porto Alegre, 2010.

RUBIO, S. et al. Evaluation of subjective mental workload: A comparison of SWAT, NASA-TLX, and workload profile methods. Applied Psychology, v. 53, n. 1, p. 6186,2004 . crossref

SCHMIDT, L.; SJÖSTRÖM, J.; ANTONSSON, A. Successful collaboration between occupational health service providers and client companies: Key factors. Work, v. 51 , n. 2, p. 229-237, 2015. crossref 
SOARES, M. Ergonomia: soluções e propostas para um trabalho melhor. Production, v. 19, n. 3, 2009. crossref

SÖRENSEN, L. E. et al. Associations between work ability, health-related quality of life, physical activity and fitness among middle-aged men. Applied ergonomics, $v$. 39, n. 6, p. 786-791, 2008. crossref

TRENTIN, M. G.; OLIVEIRA, G. A.; SETTI, D. Thermography: an a assessment tool in the Ergonomic Analysis of a Work Station in the Foundry Industry. In: International conference on industrial engineering and operations management. Guimarães, Portugal: Universidade do Minho. 2012.

VILLAROUCO, V.; ANDRETO, L. F. M. Avaliando desempenho de espaços de trabalho sob o enfoque da ergonomia do ambiente construído. Production, v. 18, n. 3, p. 523-539, 2008. crossref

VINK, P. et al. A participatory ergonomics approach to reduce mental and physical workload. International Journal of Industrial Ergonomics, v. 15, n. 5, p. 389-396, 1995. crossref

WERNER, L. et al. Análise da percepção sobre assentos de trabalho utilizando técnicas estatísticas multivariadas. Produção, v. 13, n. 3, p. 34-49, 2003. cross ref

Recebido: 12 ago. 2017

Aprovado: 16 abr. 2018

DOI: 10.3895/gi.v14n2.6966

Como citar:

LINHARES, J. E.; PESSA, S. L. R.; OLIVEIRA, G. A. TRENTIN, M. G. Ergonomic analysis in an animal feed company: demands and work environment. R. Gest. Industr., Ponta Grossa, v. 14, n. 2, p. 134-158, abr./jun. 2018. Disponível em: $\leq$ https://periodicos.utfpr.edu.br/rgi>. Acesso em: XXX.

Correspondência:

João Eduardo Linhares

Avenida Brasil, 805, apto 103, São Lourenço do Oeste, Santa Catarina, Brasil.

Direito autoral: Este artigo está licenciado sob os termos da Licença Creative Commons-Atribuição 4.0

Internacional.

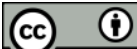

